\title{
CD1d-antibody fusion proteins target iNKT cells to the tumor and trigger long-term therapeutic responses
}

\author{
Stéphanie Corgnac $\cdot$ Rachel Perret $\cdot$ Laurent Derré $\cdot$ Lianjun Zhang $\cdot$ Kathrin Stirnemann • \\ Maurice Zauderer • Daniel E. Speiser · Jean-Pierre Mach · Pedro Romero • Alena Donda
}

Received: 17 July 2012/Accepted: 22 November 2012/Published online: 15 December 2012

(C) The Author(s) 2012. This article is published with open access at Springerlink.com

\begin{abstract}
Despite the well-established antitumor activity of CD1d-restricted invariant natural killer T lymphocytes (iNKT), their use for cancer therapy has remained challenging. This appears to be due to their strong but shortlived activation followed by long-term anergy after a single administration of the CD1d agonist ligand alpha-galactosylceramide $(\alpha \mathrm{GC})$. As a promising alternative, we obtained sustained mouse iNKT cell responses associated with prolonged antitumor effects through repeated administrations of tumor-targeted recombinant sCD1d-antitumor $\mathrm{scFv}$ fusion proteins loaded with $\alpha \mathrm{GC}$. Here, we demonstrate that CD1d fusion proteins bound to tumor cells via the antibody fragment specific for a tumor-associated antigen, efficiently activate human iNKT cell lines leading to potent tumor cell lysis. The importance of CD1d tumor targeting was
\end{abstract}

Electronic supplementary material The online version of this article (doi:10.1007/s00262-012-1381-7) contains supplementary material, which is available to authorized users.

S. Corgnac · R. Perret - L. Zhang - D. E. Speiser - P. Romero ·

A. Donda ( $\square)$

Ludwig Center for Cancer Research, University of Lausanne,

1066 Epalinges, Switzerland

e-mail: alena.donda@unil.ch

L. Derré

Urology Research Unit, Department of Urology, Lausanne

University Hospital, 1005 Lausanne, Switzerland

K. Stirnemann

Roche Pharma AG, 4153 Reinach, Switzerland

M. Zauderer

Vaccinex Inc., Rochester, NY, USA

J.-P. Mach

Department of Biochemistry, University of Lausanne,

1066 Epalinges, Switzerland confirmed in tumor-bearing mice in which only the specific tumor-targeted CD1d fusion protein resulted in tumor inhibition of well-established aggressive tumor grafts. The therapeutic efficacy correlated with the repeated activation of iNKT and natural killer cells marked by their release of TH1 cytokines, despite the up-regulation of the co-inhibitory receptor PD-1. Our results demonstrate the superiority of providing the superagonist $\alpha \mathrm{GC}$ loaded on recombinant CD1d proteins and support the use of $\alpha \mathrm{GC} / \mathrm{sCD} 1 \mathrm{~d}$-antitumor fusion proteins to secure a sustained human and mouse iNKT cell activation, while targeting their cytotoxic activity and cytokine release to the tumor site.

Keywords Cancer immunotherapy $\cdot$ iNKT cells $\cdot$ CD1d · Tumor targeting $\cdot$ Fusion protein

\section{Introduction}

Human Va24-invariant natural killer T lymphocytes (iNKT), and their murine counterparts Va14-iNKT cells, represent a particular sublineage of T lymphocytes activated by self- and microbial-derived glycolipids in the context of the monomorphic MHC-related molecule CD1d. Their importance in the transactivation of innate and adaptive immune responses has been extensively described $[1,2]$, as well as their protective or pathological role in various conditions [3]. In particular, their antitumor activity has been well documented in a number of mouse tumor models [4-6], and several clinical observations also indicate their protective role against cancer progression. Furthermore, low numbers and impaired proliferative capacity of iNKT cells were reported in cancer patients compared to normal donors [7,8], which in some studies were correlated with poor clinical outcome $[9,10]$. These preclinical and clinical observations have prompted 
testing of iNKT cell-directed therapies, mainly through their strong activation by the synthetic glycosphingolipid CD1d ligand, alpha-galactosylceramide ( $\alpha \mathrm{GC})$ [11-13]. Phase I clinical trials involving the autologous transfer of $\alpha \mathrm{GC}$ pulsed monocyte-derived dendritic cells (moDC) were conducted in patients with different types of cancer $[4,11$, 13-16]. No severe adverse effects were seen and the transient expansion and activation of iNKT cells, obtained in nonsmall-cell lung cancer (NSCLC) and head and neck squamous cell cancer (HNSCC) patients, correlated with some clinical benefit. Unfortunately, however, iNKT cell-mediated tumor immunotherapy has been limited by the short-lived cytokine response of iNKT cells to $\alpha \mathrm{GC}$ stimulation, followed by a long-term anergy $[4,17,18]$. Recently, we have instead showed that sustained mouse iNKT cell responses could be induced by repeated stimulations with recombinant aGC-loaded sCD1d fusion proteins [19]. This prolonged responsiveness of iNKT cells resulted in potent antitumor activity when CD1d was targeted to the tumor site by its fusion to an anti-HER2 antitumor antibody fragment [19]. In the present study, recombinant CD1d proteins are shown to expand and activate human iNKT cells without the need of antigen-presenting cells (APCs). Importantly, we show that human iNKT cells exhibit a potent direct cytotoxicity only against cancer cells coated with the specific sCD1d-antitumor $\mathrm{scFv}$ fusion protein. The importance of CD1d tumor targeting to promote sustained activation of iNKT cells and prolonged tumor inhibition is further characterized in mice in therapeutic settings.

\section{Materials and methods}

Mice and human samples

Female mice C57BL/6J (B6) 6-8 weeks old (Harlan, Zeist, Holland) were maintained in specific pathogen-free conditions. All animal experiments were conducted according to institutional guidelines and under an authorization delivered by the Swiss veterinary department. Fresh human PBMC were obtained from healthy donor blood, isolated by density centrifugation using Lymphoprep (Axis-Shield PoC AS, Norway).

Tumor cell lines and human iNKT cell lines and clones

The murine colon carcinoma MC-38 cell line transfected with human CEA (MC38-CEA) was a kind gift from J. Primus [20]. The human cell lines KATO III (gastric carcinoma) and SK-BR-3 (breast carcinoma) were obtained from the ATCC. The human B lymphoma cell line C1R stably transfected with human CD1d was used as APC. Alternatively, moDCs were generated as described by Shao et al. [21]. Human iNKT cell lines were established starting with fresh PBMC from healthy donors cultured with $\alpha \mathrm{GC}(100 \mathrm{ng} / \mathrm{ml})$ or $\alpha \mathrm{GC} / \mathrm{sCD} 1 \mathrm{~d}$ proteins $(40 \mu \mathrm{g} / \mathrm{ml})$ in RPMI medium with $8 \%$ human serum, recombinant IL-2 $(20 \mathrm{U} / \mathrm{ml})$ and $\mathrm{IL}-7(10 \mathrm{ng} / \mathrm{ml})$. Human iNKT cell clones had been previously generated by limiting dilution after sorting from peripheral blood lymphocytes (PBLs) of healthy donors by anti-CD3, anti-Va24, and antiV $\beta 11$ mAbs staining [22].

Reagents and antibodies

The $\alpha \mathrm{GC}$ analog KRN7000 (Alexis Biochemicals Corp) was dissolved in PBS-0.5\% Tween-20. Cytokine levels were measured either individually by ELISA (ELISA ready-setgo, eBiosciences), or as multiple cytokine measurements using BD Cytometric Bead Array kit TH1/TH2/TH17 (CBA, BD Biosciences). All fluorochrome-labeled antibodies were purchased from Becton-Dickinson (BD Biosciences) or eBiosciences. The humanized mAbs anti-HER2 Herceptin (Trastuzumab) was from Roche Ltd and anti-CEA (X4) from Ciba-Geigy [23]. Cells were analyzed with a FACSCalibur, FACSCanto or LSRII (BD Biosciences) and the acquired data were processed using FlowJo software (Tree Star Inc.).

\section{Recombinant CD1d fusion proteins}

Genetic fusion of mouse $\beta 2$ microglobulin ( $\beta 2 \mathrm{~m}$ ) with the soluble part of mouse CD1d (sCD1d) has been described previously [19]. In the original pEAK8- $\beta 2 \mathrm{~m}$-sCD1d-antiHER2-6xHIS construct, the anti-HER2 scFv located between the Gly-Ser spacer and the 6xHIS was replaced by the antiCEA scFv MFE23 (kindly provided by R.H. Begent [24]). Recombinant CD1d fusion proteins produced by transient transfection of the human cell line HEK293-EBNA (Cellular Biotechnology Laboratory, EPFL, Switzerland) were purified and loaded with $\alpha \mathrm{GC}$ as previously reported [19] (Fig. $\mathrm{S} 1)$. The CD1d tetramer was developed by engineering a BirA consensus sequence at the C-terminus of the soluble mouse CD1d protein. The CD1d monomer was biotinylated by the BirA enzyme (Avidity, Denver, $\mathrm{CO}$ ), and after loading with $\alpha \mathrm{GC}$, it was tetramerized on streptavidin-PE (Invitrogen) using a molar ratio of $4: 1$.

In vitro proliferation

Human iNKT cells were labeled with $1 \mu \mathrm{M}$ CFSE for 6 min at $37{ }^{\circ} \mathrm{C}$ and washed three times. Labeled iNKT cells were incubated in a 12 -well plate at $1 \times 10^{6}$ cells $/ \mathrm{ml}$ in RPMI with $8 \% \mathrm{HS}, 30 \mathrm{U} / \mathrm{ml} \mathrm{IL}-2$, and $10 \mathrm{ng} / \mathrm{ml} \mathrm{IL-7} \mathrm{at}$ $37{ }^{\circ} \mathrm{C}$. iNKT cells were stimulated with either $8 \times 10^{5}$ irradiated $\alpha$ GC-loaded C1R-CD1d, plastic-coated sCD1d fusion proteins $(40 \mu \mathrm{g})$, or $200 \mathrm{ng} / \mathrm{ml} \alpha \mathrm{GC}$. The dilution of CFSE was analyzed by flow cytometry. 
iNKT cell cytotoxicity

For chromium release experiments, iNKT clones, $\mathrm{CD}^{+}{ }^{+}$or double negative (DN), were thawed the day before and kept overnight in RPMI $8 \%$ HS supplemented with recombinant IL-2 $(150 \mathrm{U} / \mathrm{ml})$ and IL-7 $(10 \mathrm{ng} / \mathrm{ml})$. On the day of the experiment, target cells were labeled with ${ }^{51} \mathrm{Cr}$ for $1 \mathrm{~h}$ at $37^{\circ} \mathrm{C}$ and washed three times in medium before incubation $\left(10^{3}\right.$ cells per well) in $96 \mathrm{~V}$-bottom well plates either with effector cells at an E:T ratio of 10:1 and different concentration of CD1d-recombinant molecules, or in the presence of different E: $T$ ratios and a fixed concentration of CD1d-recombinant molecules $(10 \mu \mathrm{g} / \mathrm{ml})$. Supernatants were collected after $4 \mathrm{~h}$ of incubation at $37^{\circ} \mathrm{C}$, and released radioactivity was measured in a $\gamma$-counter. For Annexin V analysis, $2 \times 10^{5} \mathrm{NKT}$ cells were incubated with $1 \times 10^{4}$ tumor cells in the presence of either $\alpha \mathrm{GC} /$ sCD1d-antitumor scFv at $10 \mu \mathrm{g} / \mathrm{ml}$ in RPMI $8 \%$ human serum or $5 \times 10^{4} \alpha \mathrm{GC} / \mathrm{C} 1 \mathrm{R}-\mathrm{CD} 1 \mathrm{~d}$ cells or $5 \times 10^{4} \alpha \mathrm{GC} /$ moDCs for $4 \mathrm{~h}$ at $37^{\circ} \mathrm{C}$. After incubation, tumor cells and APCs were analyzed using Annexin V kit (BD Pharmingen) and CD1d-tetramer-positive iNKT cells were stained for CD107a and intracellular content of IFN $\gamma$ and TNF $\alpha$.

\section{Antitumor therapy}

Mice were grafted s.c. in the right flank with $7 \times 10^{5}$ MC38-CEA cells. When all tumors were palpable, mice were treated i.v. with $200 \mu \mathrm{l}$ of either PBS alone, equimolar amounts of $\alpha \mathrm{GC}(0.4 \mu \mathrm{g}), \alpha \mathrm{GC} / \mathrm{sCD} 1 \mathrm{~d}(25 \mu \mathrm{g})$, or $\alpha \mathrm{GC} / \mathrm{CD} 1 \mathrm{~d}$-antitumor scFv fusion proteins $(40 \mu \mathrm{g})$. Systemic treatment was repeated at 3- to 4-day intervals. Mean tumor volume measured every 2 days was calculated using the following formula: (length $\times$ width $\times$ thickness $) / 2$.

\section{Statistical analysis}

Results are expressed as mean \pm SEM. Statistical significance between the groups was determined with student's $t$ test or one-way -ANOVA test with Bonferroni correction (GraphPad Prism, GraphPad software). Tumor progression statistics were calculated with two-way ANOVA test with Bonferroni correction (GraphPad Prism, GraphPad software).

\section{Results}

Human iNKT cells efficiently proliferate in the presence of $\alpha \mathrm{GC}$-loaded CD1d protein

To validate the usefulness of soluble recombinant CD1d proteins for clinical immunotherapy, we investigated the reactivity of human iNKT cells to mouse $\alpha \mathrm{GC} / \mathrm{sCD} 1 \mathrm{~d}$ or $\alpha \mathrm{GC} / \mathrm{sCD} 1 \mathrm{~d}$-antitumor $\mathrm{scFv}$ proteins. Irrespectively of whether fused or not to an antitumor $\mathrm{scFv}$ fragment, all sCD1d fusion proteins in solution were able to expand iNKT cell lines from freshly isolated human PBMC. The kinetics of expansion was similar to that observed following exposure to free $\alpha \mathrm{GC}$ (Fig. 1a), with approximately $40 \%$ iNKT cells on day 7 and $60 \%$ on day 14 of culture. All iNKT cell lines, whether expanded with free $\alpha \mathrm{GC}$ or aGC-loaded sCD1d fusion proteins, retained the same subset composition, with a majority of DN and a minority of $\mathrm{CD}^{+}$iNKT cells (Fig. 1b). Importantly, recombinant $\alpha \mathrm{GC} / \mathrm{sCD} 1 \mathrm{~d}$ proteins could directly expand pure iNKT cell populations, as seen by CFSE dilution (Fig. 1c) and increased numbers of iNKT cells over 5 days of culture (data not shown), whereas the addition of irradiated APCs was required for free $\alpha \mathrm{GC}$ to induce iNKT cell proliferation. These data indicate that $\alpha \mathrm{GC}$-loaded recombinant CD1d proteins directly trigger the semi-invariant TCR of human iNKT cells, and thus represent a promising tool for rapid and potent expansion of human iNKT cells from patients for subsequent adoptive cell transfer.

Soluble CD1d proteins directly activate human iNKT cell clones without requirement for APCs

As suggested by the expansion of human iNKT cells, aGCloaded sCD1d proteins did not require the presence of APCs and were sufficient to activate human iNKT cell clones to release IFN $\gamma$ after 18-h incubation (Fig. 2a). In contrast, $\alpha \mathrm{GC}$ as a free drug was unable to activate iNKT cell clones in the absence of APCs (Fig. 2a) and required the presence of CD1d-expressing cells such as the human lymphoma C1R transfected with CD1d (Fig. 2b). These data fully established that the activation of human iNKT cells by soluble CD1d proteins did not result from the transfer of $\alpha \mathrm{GC}$ to endogenously expressed CD1d, but rather from the direct TCR triggering by the soluble fusion proteins. As shown for iNKT cell proliferation, plasticcoated sCD1d proteins were even more efficient than soluble proteins in inducing iNKT cell clones to release a panel of cytokines such as IFN $\gamma$, TNF $\alpha$, IL-2, and IL-4 (Fig. 2b). Still, when compared to aGC loaded on C1RCD1d APCs, sCD1d proteins remained about threefold weaker in activating iNKT cells, likely resulting from the lack of adhesion mechanisms and molecular aggregation provided by cell-cell interaction.

Human iNKT cells efficiently kill tumor cells only when coated with the sCD1d-antitumor fusion protein

In view of the rare expression of CD1d on tumor cells, the direct cytotoxicity of iNKT cells against tumors has been disregarded, and instead, the immediate antitumor activity 

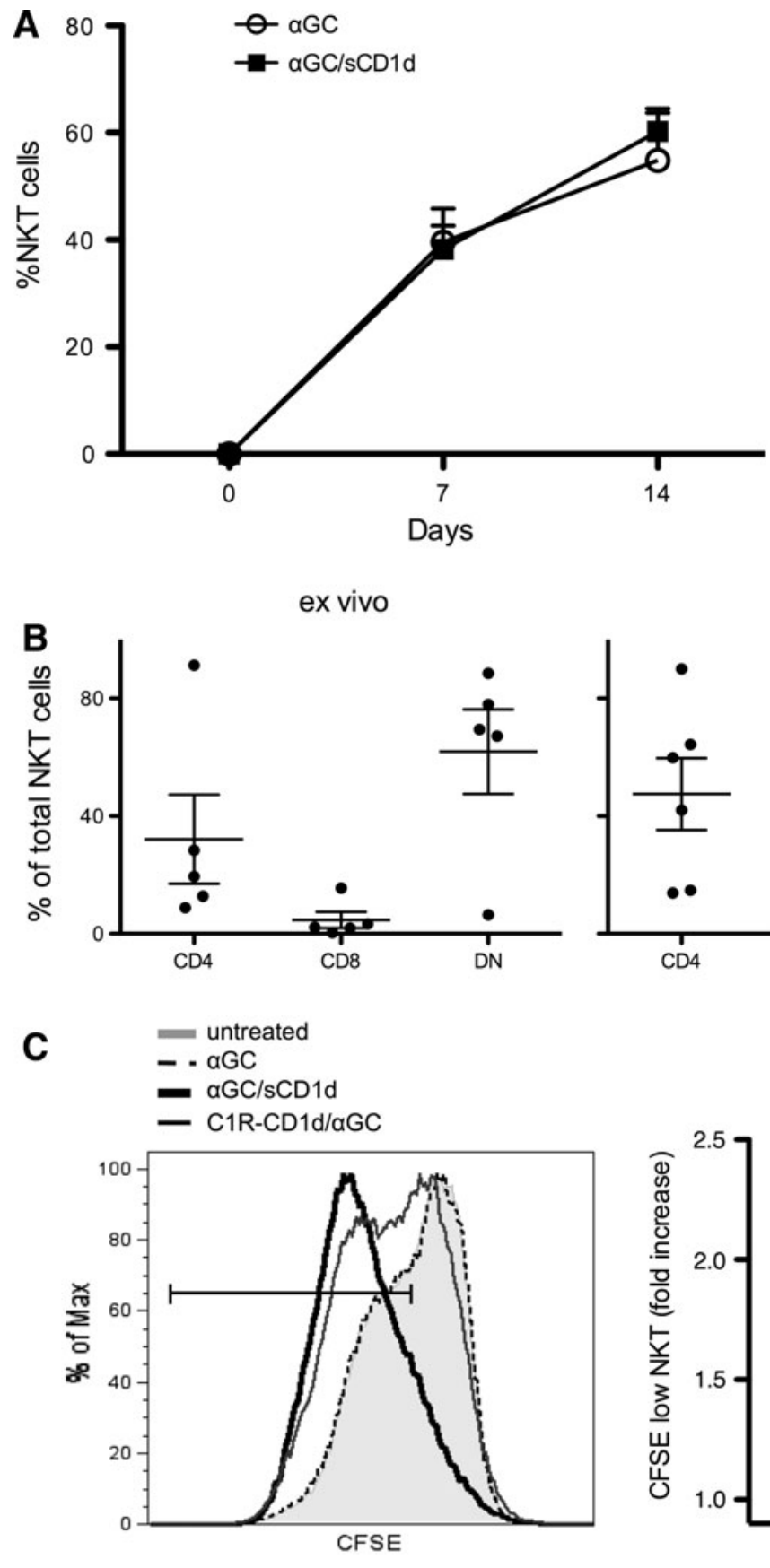

aGC

\section{$\alpha \mathrm{GC} / \mathrm{sCD} 1 \mathrm{~d}$}
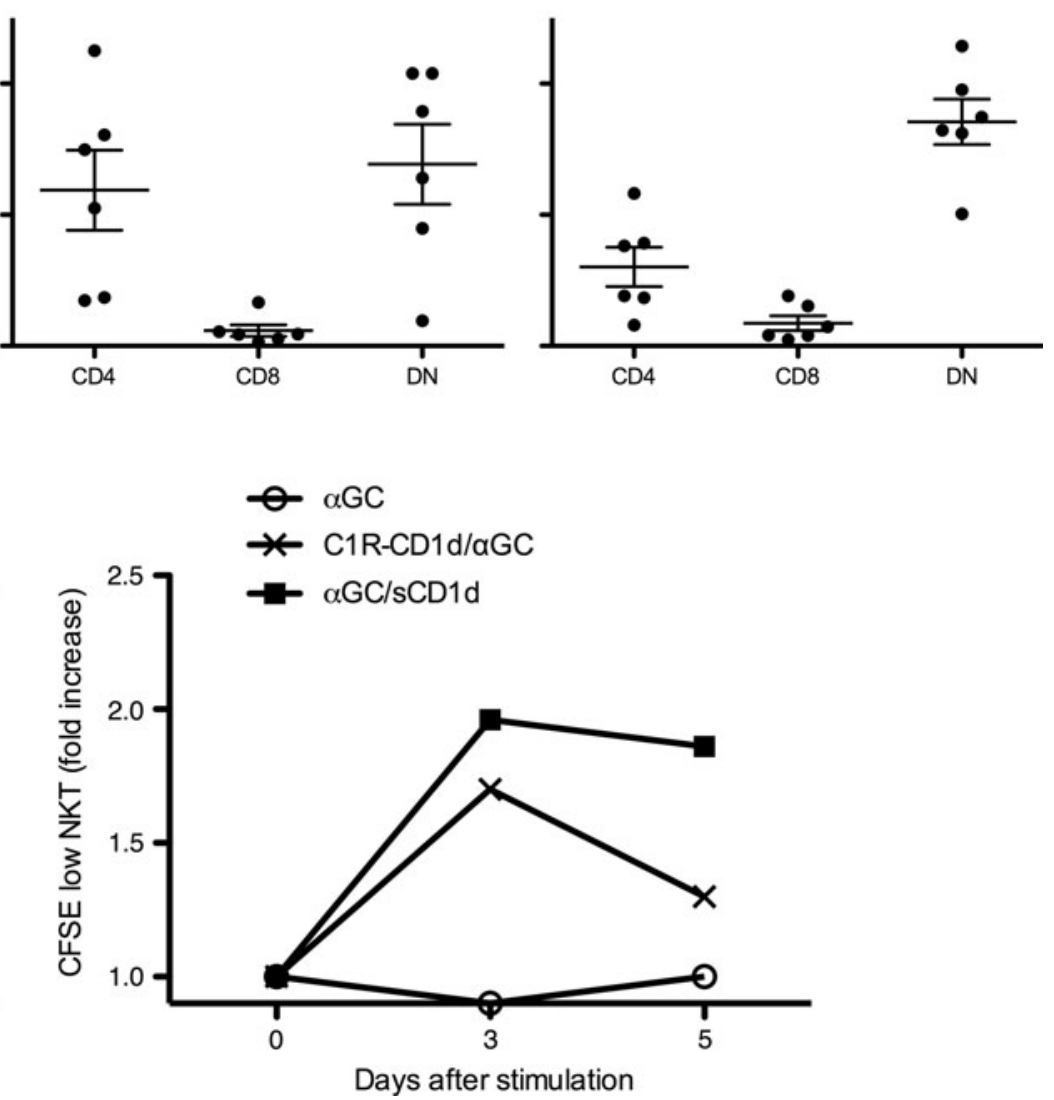

Fig. 1 Expansion of human iNKT cell lines by $\alpha \mathrm{GC} / \mathrm{sCD} 1 \mathrm{~d}$ proteins. a PBMCs from healthy donors were stimulated with medium alone, $\alpha \mathrm{GC}(100 \mathrm{ng} / \mathrm{ml})$ or $\alpha \mathrm{GC} / \mathrm{sCD} 1 \mathrm{~d}$ protein $(10 \mu \mathrm{g} / \mathrm{ml})$. Frequency of iNKT cells in total PBMC was assessed as CD1d-tetramer ${ }^{+} \mathrm{CD}^{+}$at day 0,7 , and 14 of culture. Results are shown as mean \pm SEM of four donors. b Distribution of human iNKT cell subsets ex vivo and after 14 days of culture as described in a. Dots represent percentages of $\mathrm{CD} 4, \mathrm{CD} 8$, and DN iNKT cells in total CD1d-tetramer ${ }^{+} \mathrm{CD}^{+}$from

normal individuals or expanded cell lines, and bars show mean \pm SEM. c CFSE-labeled iNKT cells were incubated for 5 days with the different stimuli, and CFSE dilution was analyzed by FACS on gated CD1d-tetramer ${ }^{+} \mathrm{CD}^{+}$cells. Left panel illustrates CFSE fluorescence in iNKT cells on day 5 of culture. Right panel shows the kinetic of CFSE dilution as the fold increase of CFSE ${ }^{\text {low }}$ iNKT cells. Results shown are representative of three independent experiments

of iNKT cells was shown to be largely mediated by the transactivation of natural killer cells $[5,19,25]$. However, direct cytotoxicity of human iNKT cells has been well

demonstrated, especially against CD1d-expressing leukemia in vitro and in vivo [26, 27]. Here, we show that the killing capacity of human iNKT cells can be extended 

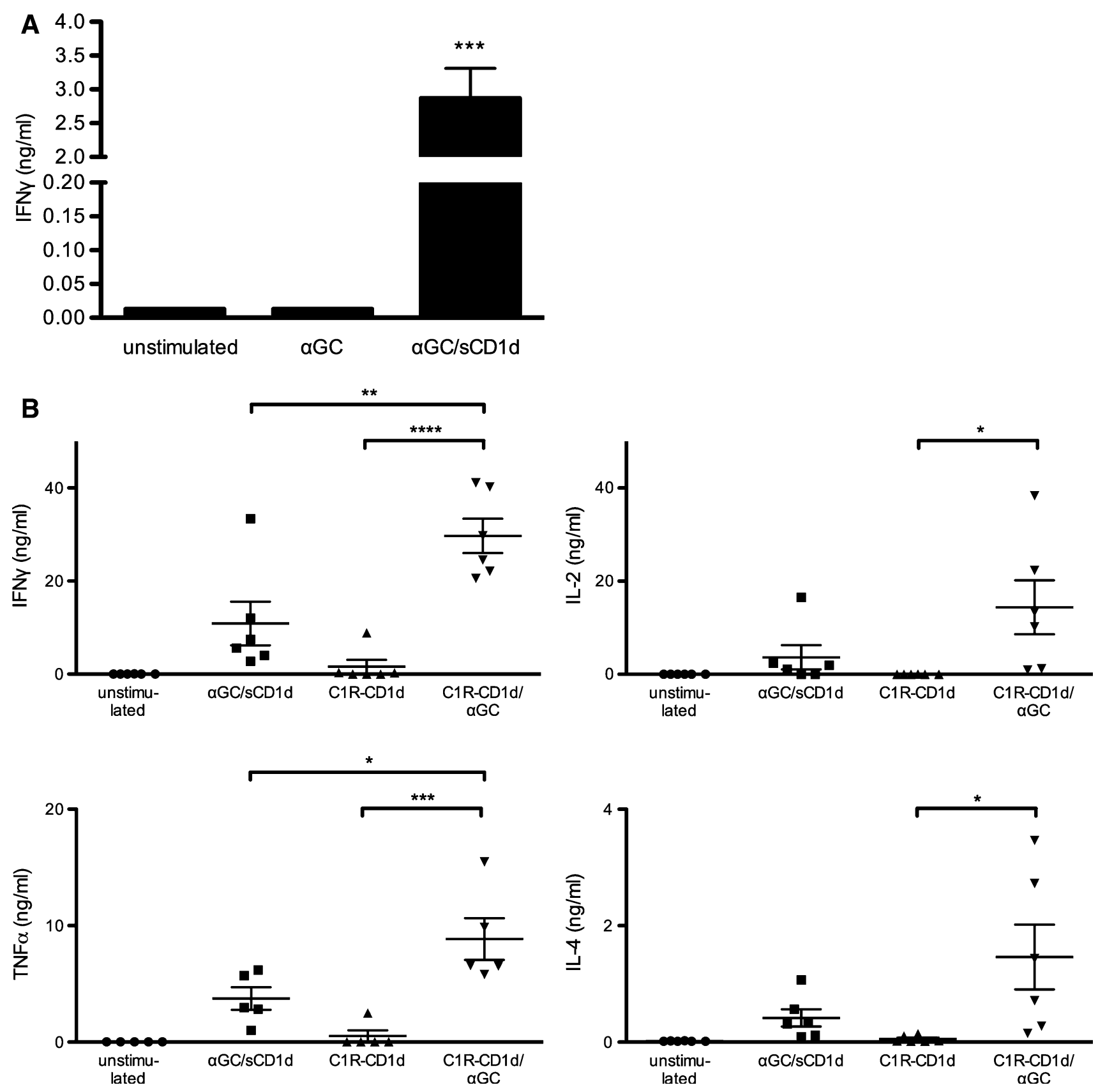

Fig. 2 Human iNKT cells are directly activated by recombinant $\alpha \mathrm{GC} / \mathrm{sCD} 1 \mathrm{~d}$ proteins. a iNKT cell clones $\left(10^{5}\right)$ were incubated for $18 \mathrm{~h}$ with $\alpha \mathrm{GC}(100 \mathrm{ng} / \mathrm{ml})$ or $\alpha \mathrm{GC} / \mathrm{sCD} 1 \mathrm{~d}$ proteins in solution $(10 \mu \mathrm{g} / \mathrm{ml})$. Graph shows the level of IFN $\gamma$ in the supernatant as the mean \pm SEM of three different human iNKT cell clones. $* * * P<0.001$. b Activation of iNKT cells by $\alpha \mathrm{GC} / \mathrm{sCD} 1 \mathrm{~d}$ proteins

against CD1d-negative tumor cells by their coating with $\alpha \mathrm{GC} / \mathrm{CD} 1 \mathrm{~d}-$ antitumor $\mathrm{scFv}$ fusion proteins. Two human tumor cell lines were selected based on their expression of HER2 and/or CEA (Fig. 3a). The pancreatic tumor cell line KATO III expresses both HER2 and CEA, as shown by the binding of the specific antibodies, as well as of the corresponding sCD1d-anti-HER2 and the newly developed

or $\alpha$ GC-pulsed APCs. Human iNKT cell clones $\left(10^{5}\right)$ were incubated with no stimulus, with plastic-coated $\alpha \mathrm{GC} / \mathrm{sCD} 1 \mathrm{~d}$ proteins $(10 \mu \mathrm{g})$ or with the B-cell lymphoma cell line C1R-CD1d $\left(5 \times 10^{4}\right)$ pulsed or not with $\alpha \mathrm{GC}$. After $24 \mathrm{~h}$, cytokines were measured in supernatants by CBA. $* P<0.01 * * P<0.005, * * * P<0.001, * * * * P<0.0001$

sCD1d-anti-CEA fusion proteins (Fig. S1). In contrast, the breast cancer cell line SKBR-3 highly expresses HER2 but is negative for CEA, which provided the possibility of evaluating targeted versus untargeted iNKT cell-mediated cytotoxicity. After 4-h incubation with iNKT cells, tumor cells were killed only when coated with the relevant $\mathrm{sCD} 1 \mathrm{~d}-\mathrm{scF}$ v fusion proteins. Indeed, KATO III tumor cells 
A
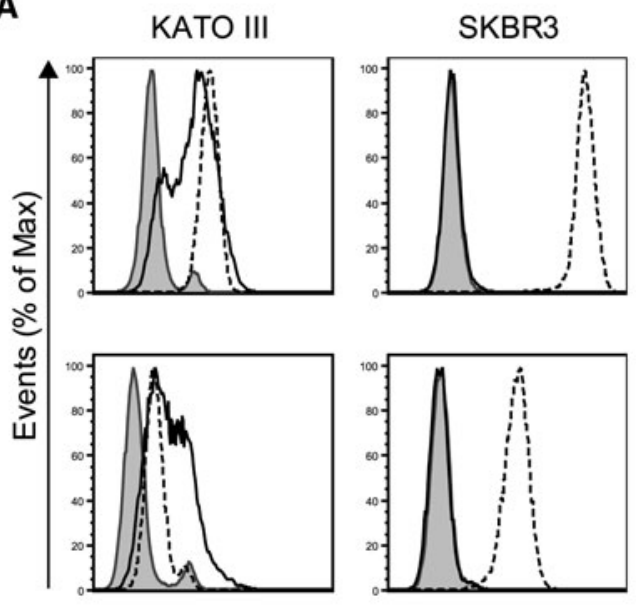

B

KATO III
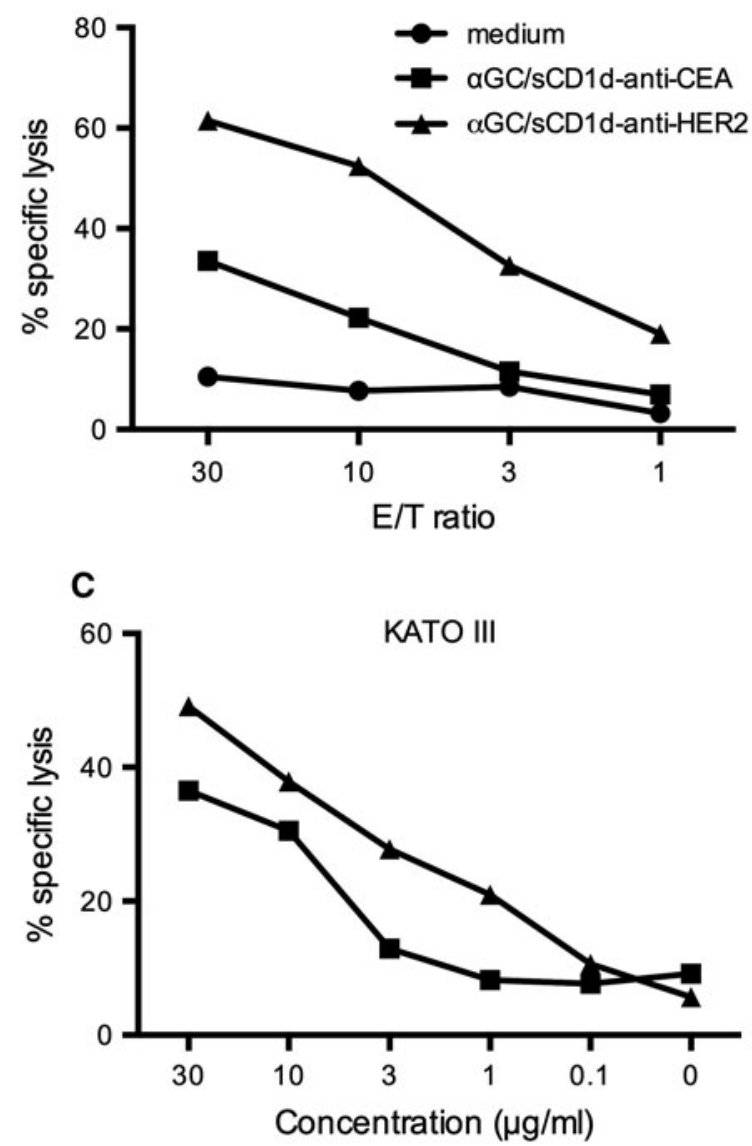

Fig. 3 Human iNKT cells efficiently kill tumor cells only when coated with the $\alpha \mathrm{GC} / \mathrm{sCD} 1 \mathrm{~d}$-antitumor fusion protein. a Expression of HER2 and CEA by KATO III and SKBR3 human tumor cells revealed either by the anti-HER2 (Herceptin) and anti-CEA (X4) mAbs (upper panels), or by the binding of sCD1d-anti-CEA and sCD1d-anti-HER2 fusion proteins, revealed by FITC-labeled anti$\mathrm{CD} 1 \mathrm{~d}$ (lower panels). ${ }^{51} \mathrm{Cr}$ release assay after 4-h incubation of iNKT cell clones with the tumor cell lines described in a. Graph

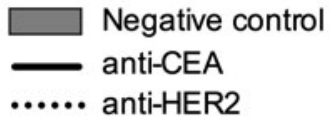

$\square$ Negative control aGC/sCD1d-anti-CEA aGC/sCD1d-anti-HER2
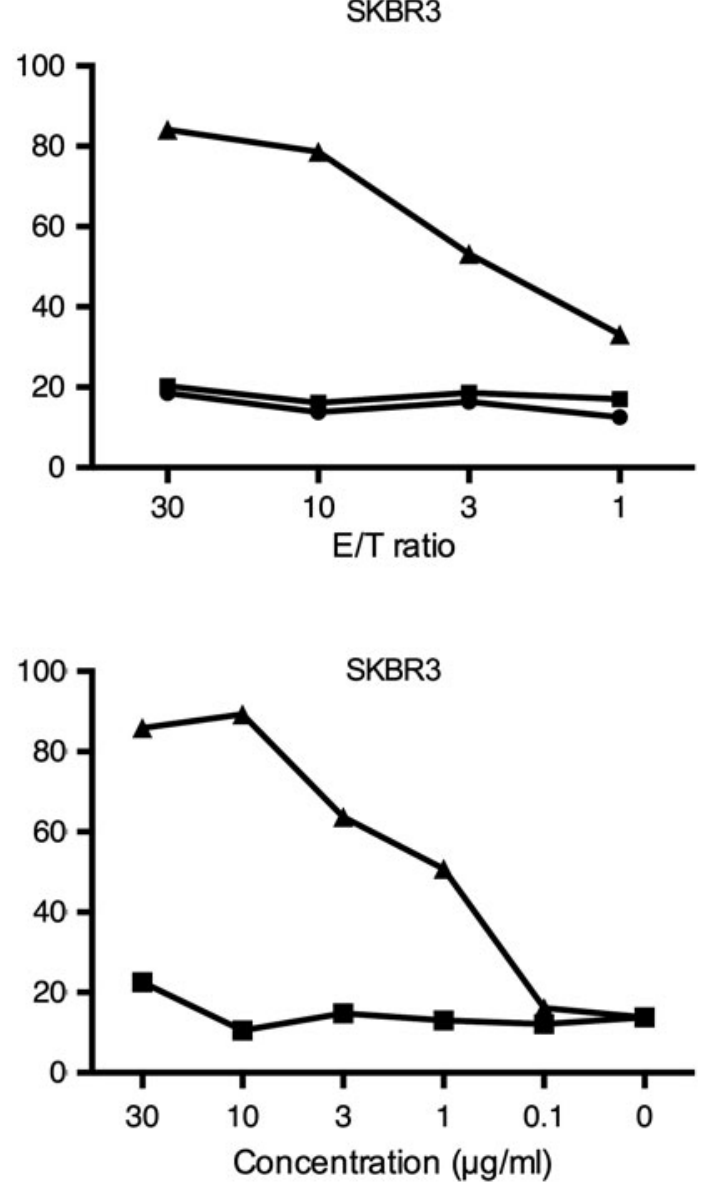

curves show percent killing of KATO III (left panel) and SKBR-3 cells (right panel) with decreasing effector-to-target ratio $(E / T)$ with $2 \times 10^{3}$ target tumor cells and $10 \mu \mathrm{g} / \mathrm{ml}$ of sCD $1 \mathrm{~d}$ fusion proteins. c Panels show percent killing of KATO III (left) and SKBR-3 cells (right) with decreasing concentrations of sCD1d fusion proteins at an E/T ratio of 10/1. Results shown are representative of three independent experiments 
co-expressing HER2 and CEA were killed in the presence of either of the two $\alpha \mathrm{GC} / \mathrm{sCD} 1 \mathrm{~d}$-antitumor proteins (Fig. 3b, left panel), with 40 and $60 \%$ of tumor cells killed at an E/T ratio of $30 / 1$ and $10 \mu \mathrm{g} / \mathrm{ml}$ of $\alpha \mathrm{GC} / \mathrm{sCD} 1 \mathrm{~d}-\mathrm{anti}-$ HER2 and $\alpha \mathrm{GC} / \mathrm{sCD} 1 \mathrm{~d}$-anti-CEA fusion proteins, respectively. In contrast, the SKBR-3 tumor cells expressing only HER2 were exclusively killed when incubated with the aGC/sCD1d-anti-HER2 protein (Fig. 3b, right panel), with $80 \%$ of cells eliminated, while co-incubation with the $\alpha \mathrm{GC} / \mathrm{sCD} 1 \mathrm{~d}$-anti-CEA protein resulted in only background ${ }^{51} \mathrm{Cr}$ release similar to medium alone. At an $\mathrm{E} / \mathrm{T}$ ratio of 10/1 (Fig. 3c), $20 \%$ targeted killing of KATO III (left panel) and $50 \%$ killing of SKBR-3 (right panel) tumor cells was still obtained with $1 \mu \mathrm{g} / \mathrm{ml}(13 \mathrm{nM})$ of HER2 and/ or CEA-targeted CD1d fusion proteins, demonstrating the sensitivity of this approach. All iNKT cell clones tested in cytotoxic assays were $\mathrm{CD}^{+}$or $\mathrm{DN}$ and showed similar capacity of tumor-targeted cell killing.

Activated iNKT cells exhibit poor bystander cytotoxicity and selectively kill CD1d-positive target cells

In addition to ${ }^{51} \mathrm{Cr}$ release experiments, the killing of SKBR3 tumor cells was evidenced by their Annexin $\mathrm{V}^{+}$ $7-\mathrm{AAD}^{-}$profile, while the state of iNKT cell activation was evaluated by CD107a expression, and secretion of $\mathrm{TNF} \alpha$ and IFN $\gamma$ (Fig. 4). After 4-h incubation with human iNKT cells, an average of $60 \%$ of SKBR3 tumor cells was apoptotic when incubated with the tumor-targeted $\alpha \mathrm{GC} /$ sCD1d-anti-HER2 fusion protein, while there was a similar background of tumor cell death with the untargeted $\alpha \mathrm{GC} /$ sCD1d-anti-CEA or with unstimulated iNKT cells (Fig. 4a). Interestingly, when instead of recombinant CD1d proteins, iNKT cells and SKBR-3 tumor cells were coincubated with $\alpha \mathrm{GC}$-pulsed C1R-CD1d cells or moDCs, less than $20 \%$ of SKBR3 cells became Annexin V positive (Fig. 4a), although the percentages of CD107a, IFN $\gamma$ and TNF $\alpha$-positive iNKT cells (Fig. 4b, c) were similar after incubation with the tumor-targeted $\alpha \mathrm{GC} / \mathrm{sCD} 1 \mathrm{~d}$-anti-HER2 protein or with $a \mathrm{GC} / \mathrm{C} 1 \mathrm{R}-\mathrm{CD} 1 \mathrm{~d}$ cells. The iNKT cell activation was slightly weaker in the presence of $\alpha \mathrm{GC}$ / moDCs (Fig. 4b, c), likely resulting from their hundred times lower CD1d expression than the C1R-CD1d transfectant. In addition, the state of activation of iNKT cells incubated with the $\alpha \mathrm{GC} / \mathrm{sCD} 1 \mathrm{~d}$-anti-CEA did not differ from unstimulated iNKT cells (Fig. S2). In conclusion, the similar percentages of activated iNKT cells stimulated by $\alpha \mathrm{GC}$-pulsed APCs or by tumor-targeted $\alpha \mathrm{GC} / \mathrm{sCD} 1 \mathrm{~d}-\mathrm{anti}-$ HER2 protein did not correlate with a similar killing of SKBR3 tumor cells, but rather with the concomitant elimination of the $\alpha \mathrm{GC} / \mathrm{APCs}$, as shown by, respectively, 26 and $36 \%$ of Annexin $\mathrm{V}^{+} \alpha \mathrm{GC} / \mathrm{C} 1 \mathrm{R}-\mathrm{CD} 1 \mathrm{~d}$ and $\alpha \mathrm{GC} /$
moDCs (Fig. 4a). Altogether, these data further confirmed the requirement of CD1d on the surface of the target cell for efficient killing, whether naturally expressed on the surface or bound via its fusion to an antitumor scFv fragment. The activation of iNKT cells by tumor-targeted CD1d molecules was also evidenced by their cytokine content (Fig. 4c). Indeed, in the presence of SKBR3 tumor cells coated with $\alpha \mathrm{GC} / \mathrm{sCD} 1 \mathrm{~d}$-anti-HER2, about half of iNKT cells was positive for $\mathrm{TNF} \alpha$ and $\mathrm{IFN} \gamma$, while no intracellular cytokines were detected in the presence of the irrelevant $\alpha \mathrm{GC} / \mathrm{sCD} 1 \mathrm{~d}-\mathrm{anti}-\mathrm{CEA}$ fusion protein. Altogether, these results support the relevance of sCD1d-antitumor fusion proteins for cancer therapy, as seen by the strong activation of human iNKT cells, revealed by direct tumor cytotoxicity and cytokine release.

In vivo targeting of $\alpha \mathrm{GC}$-loaded CD1d proteins to the tumor site is required for prolonged iNKT cell-mediated tumor inhibition

The importance of targeting $\alpha \mathrm{GC} / \mathrm{sCD} 1 \mathrm{~d}$ fusion proteins to the tumor was further investigated in C57BL/6 mice grafted with the MC38 colon carcinoma cell line stably transfected with human CEA (MC38-CEA). Mice with established tumors $\left(>100 \mathrm{~mm}^{3}\right)$ were treated either with $\alpha \mathrm{GC} / \mathrm{sCD} 1 \mathrm{~d}$-anti-CEA fusion protein (Fig. S1), $\alpha \mathrm{GC}$ alone, untargeted $\alpha \mathrm{GC} / \mathrm{sCD} 1 \mathrm{~d}$ or $\alpha \mathrm{GC} / \mathrm{sCD} 1 \mathrm{~d}$-anti-HER2 fusion proteins. After a total of six injections given over 3 weeks, all mice treated with $\alpha \mathrm{GC} / \mathrm{sCD} 1 \mathrm{~d}$-anti-CEA protein retained small tumors barely exceeding $200 \mathrm{~mm}^{3}$, and hence $60 \%$ smaller than in untreated animals $\left(700 \mathrm{~mm}^{3}\right)$ (Fig. 5a). In marked contrast, $\alpha \mathrm{GC}$ alone and untargeted sCD1d were unable to inhibit tumor growth. The requirement of tumor-targeted CD1d treatment to achieve a therapeutic effect was best demonstrated in the mice treated with the irrelevant $\alpha \mathrm{GC} / \mathrm{sCD} 1 \mathrm{~d}$-anti-HER2 fusion protein, as all animals had fast tumor growth. The prolonged reactivity of iNKT cells was tested in the spleen by the detection of ex vivo IFN $\gamma$ production $1 \mathrm{~h}$ after the sixth injection. After repeated injections of $\alpha \mathrm{GC}$, only few iNKT cells still produced IFN $\gamma$, confirming the induction of anergy upon repetitive stimulations (Fig. 5b) [18, 19]. Similarly, no significant IFN $\gamma$ was detected after untargeted $\alpha \mathrm{GC} / \mathrm{sCD} 1 \mathrm{~d}$ and irrelevant $\alpha \mathrm{GC} / \mathrm{sCD} 1 \mathrm{~d}$-anti-HER2 treatments, though in this case likely resulting from a weak activation of iNKT cells rather than anergy. In contrast, $15 \%$ of spleen iNKT cells isolated from mice treated with tumor-targeted $\alpha \mathrm{GC} / \mathrm{sCD} 1 \mathrm{~d}$-anti-CEA were positive for IFN $\gamma$, which correlated with the fact that antitumor activity was exclusively obtained in this group. Although tumorinfiltrating iNKT cells were too few to be functionally analyzed, the prolonged reactivity of iNKT cells only in the spleens of mice treated with tumor-targeted fusion protein 

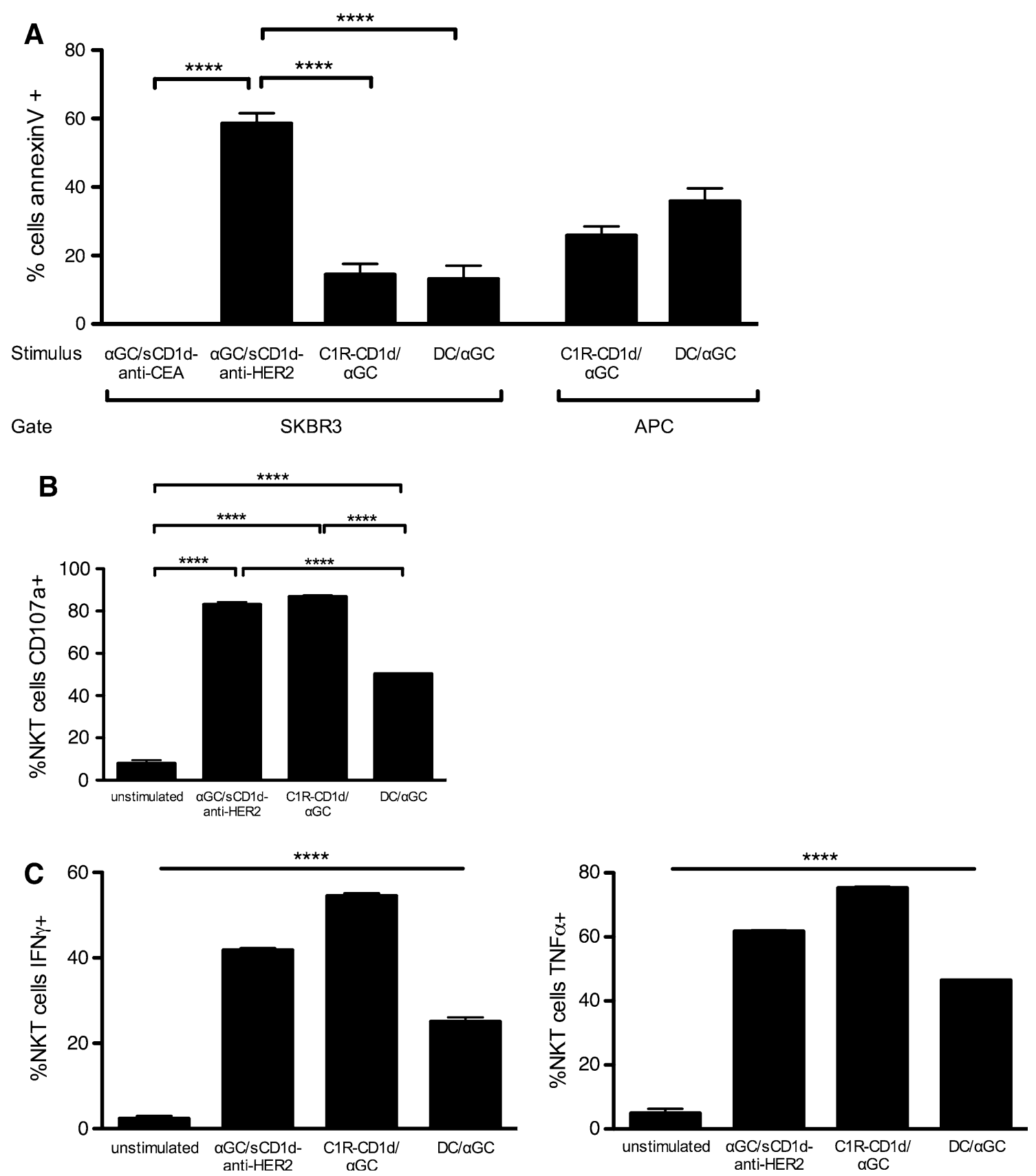

Fig. 4 Activated iNKT cells kill $\alpha \mathrm{GC} / \mathrm{sCD} 1 \mathrm{~d}-$ loaded tumor cells as well as CD1d-positive APCs. a Apoptosis of SKBR3 tumor cells or APCs after 4-h incubation with iNKT cell clones, in the presence of $\alpha$ GC/sCD1d-CEA, $\alpha$ GC/sCD1d-HER2, $\alpha$ GC-pulsed C1R-CD1d cells, or $\alpha \mathrm{GC}$-pulsed moDCs. Results are shown as percentages of Annexin $\mathrm{V}^{+} 7 \mathrm{AAD}^{-}$cells gated on HER2 ${ }^{+}$SKBR- 3 cells, CD20 ${ }^{+}$C1R-CD1d, or $\mathrm{CD} 11 \mathrm{c}^{+}$moDCs, after subtracting the respective backgrounds obtained with unstimulated iNKT cells. $* * P<0.005$. b Cytotoxic

activity of iNKT cells in the same experiment described in a was determined by assessing CD107a expression on the $\mathrm{CD}^{+} \mathrm{CD} 1 \mathrm{~d}-$ tetramer $^{+}$effector cells. $* * * P<0.001$. c The activation state of iNKT cells was also evaluated by ICS for IFN $\gamma$ and TNF $\alpha$. The unstimulated group consists of the pooled data of iNKT cells incubated with unpulsed C1R-CD1d cells or moDCs. $* * * * P<0.0001$ between all groups

suggested that these cells had been repeatedly activated at the tumor site. In view of previous studies that attributed aGC-induced iNKT cell anergy to the up-regulation of the co-inhibitory receptor programmed death-1 (PD-1) [28, 29], we tested its expression level on spleen iNKT cells

(Fig. 5c). Strikingly, PD-1 expression was up-regulated not only on the vast majority of iNKT cells after six injections of $\alpha \mathrm{GC}$ alone, but also after repeated injections of recombinant $\alpha \mathrm{GC} / \mathrm{sCD} 1 \mathrm{~d}$ proteins, including iNKT cells activated by the tumor-targeted $\alpha \mathrm{GC} / \mathrm{sCD} 1 \mathrm{~d}$-anti-CEA 
Fig. 5 In vivo antitumor activity of $\alpha \mathrm{GC} / \mathrm{sCD} 1 \mathrm{~d}$-anti-CEA fusion protein. a Mice were grafted s.c. with $7 \times 10^{5}$ MC38-CEA tumor cells. I.v. injections of PBS (untreated), or equimolar amounts of $\alpha \mathrm{GC}, \alpha \mathrm{GC}$-loaded sCD1d, $\alpha \mathrm{GC} / \mathrm{sCD} 1 \mathrm{~d}-$ anti-HER2, and $\alpha \mathrm{GC} / \mathrm{sCD} 1 \mathrm{~d}-$ anti-CEA were started 6 days later when all tumors were well established and were repeated for a total of 5 injections as specified. Tumors were measured every 2 days and the graph represents the kinetic of tumor growth $\left(\mathrm{mm}^{3}\right)$ as the mean of 7 mice per group. $* * * P<0.001$ versus untreated group. $\mathbf{b}$ Ex vivo IFN $\gamma$ production by spleen iNKT cells at the end of the antitumor experiment (day 22). Splenocytes were isolated $1 \mathrm{~h}$ after the sixth injection of each treatment and iNKT cells were stained with CD1d-tetramer-PE and anti-CD3-FITC, and intracellularly with anti-IFN $\gamma$-APC. Results are expressed as the mean percentage of IFN $\gamma$-producing iNKT of three mice per group. ${ }^{* * *} P<0.001$ versus all groups. $\mathbf{c}$ The same samples as in $\mathbf{b}$ were analyzed for the expression of the co-inhibitory receptor PD-1 on spleen iNKT cells. The graph represents the percentage of PD-1 positive iNKT cells from three mice per group. $* * P<0.005$, $* * * P<0.001, * * * * P<0.0001$ versus untreated group

protein (Fig. 5b). Therefore, increased PD-1 expression did not correlate with the state of unresponsiveness of iNKT cells. At this point, it is interesting to mention that the majority of human iNKT cells were found positive for PD1 expression when analyzed ex vivo in normal donor PBMCs (Fig. S3), likely resulting from previous in vivo stimulations. These observations suggest that PD-1 upregulation on mouse and human iNKT cells is rather a marker of activation and is not in itself sufficient to mediate iNKT cell anergy.

The prolonged reactivity of iNKT and NK cells to repeated stimulations is optimized by tumor bound CD1d proteins

The requirement for CD1d tumor targeting to provide sustained reactivity of iNKT despite PD-1 up-regulation was further characterized. As already reported [18, 19], a single injection of $\alpha \mathrm{GC}$ induced a fast and potent activation of iNKT cells, as revealed by the presence of $40 \%$ splenic iNKT cells producing IFN $\gamma$ (Fig. 6a). However, after three injections of $\alpha \mathrm{GC}$ and despite similar numbers of iNKT cells (data not shown), only $12 \%$ of iNKT cells still produced IFN $\gamma$ (Fig. 6a), confirming the induction of anergy upon repetitive stimulations $[18,19]$. In contrast, $25 \%$ of iNKT cells from MC-38-CEA tumor-bearing mice treated with $\alpha \mathrm{GC} / \mathrm{sCD} 1 \mathrm{~d}-\mathrm{anti}-\mathrm{CEA}$ fusion protein still produced IFN $\gamma$ (Fig. 6a), while only $9 \%$ iNKT cells were IFN $\gamma^{+}$in mice treated with the irrelevant $\alpha \mathrm{GC} / \mathrm{sCD} 1 \mathrm{~d}$-anti-HER2 fusion protein. Importantly, after three treatments, percentages of IFN $\gamma$-producing cells were similar whether gated on total or on PD- $1^{+}$iNKT cells (Fig. 6a), confirming that PD-1 up-regulation was not sufficient to block the restimulation of iNKT cells. In view of their fast transactivation by iNKT cells, NK cells were tested in the same groups of mice (Fig. 6b). After three injections of

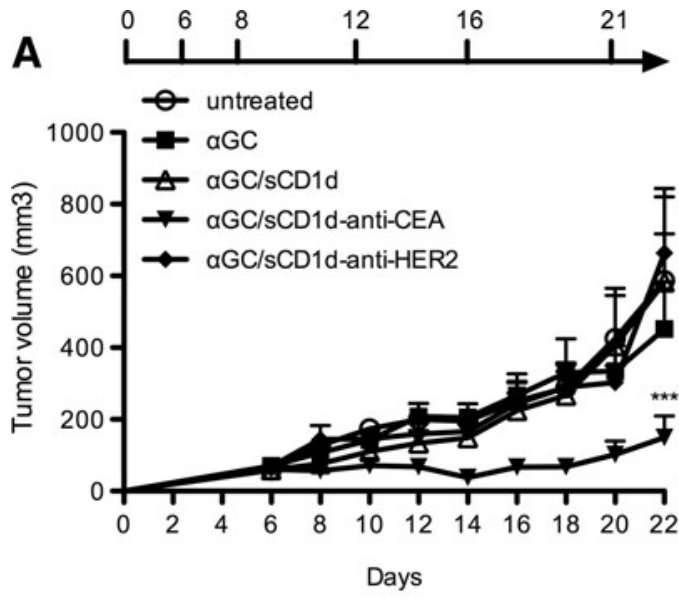

B
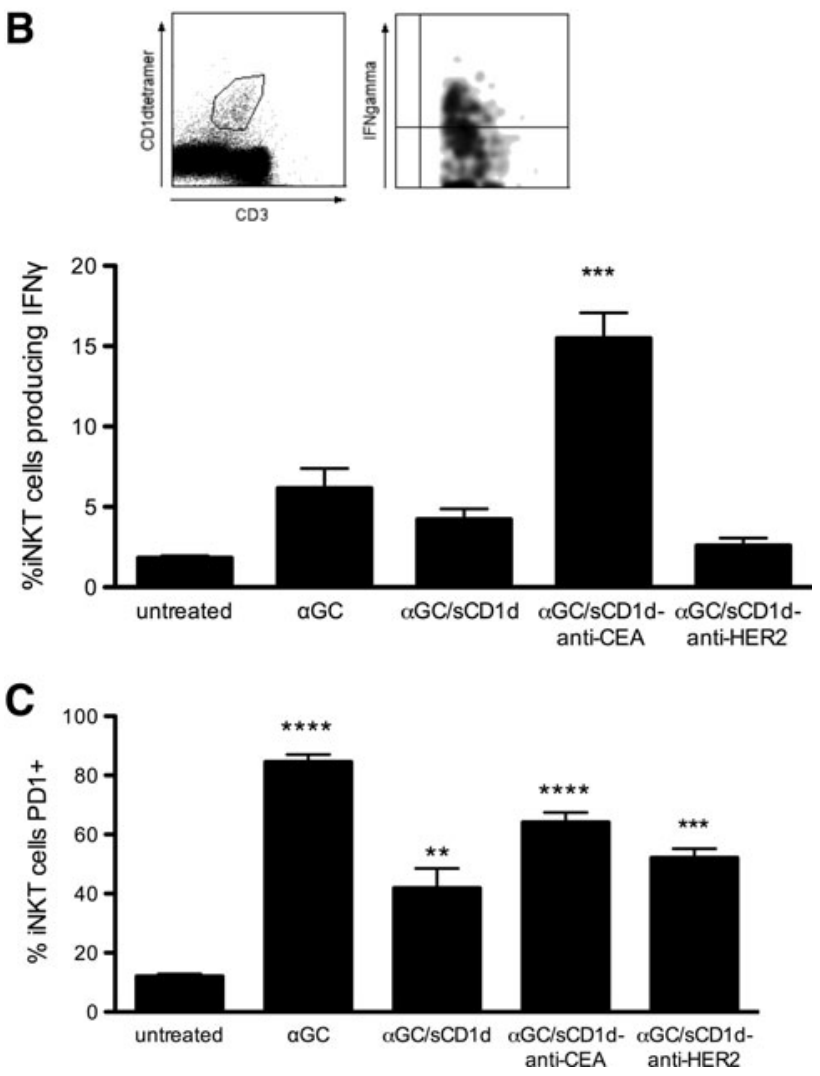

$\alpha \mathrm{GC}$, spleen NK cells also failed to produce IFN $\gamma$, as a consequence of iNKT cell anergy. In contrast, in mice treated with either $\alpha \mathrm{GC} / \mathrm{sCD} 1 \mathrm{~d}$-anti-CEA or $\alpha \mathrm{GC} / \mathrm{sCD} 1 \mathrm{~d}$ anti-HER2 fusion proteins, NK cells remained reactive, as seen by increased IFN $\gamma$ production. The repeated activation of NK cells upon treatment with the irrelevant fusion protein $\alpha \mathrm{GC} / \mathrm{sCD} 1 \mathrm{~d}$-anti-HER2 indicated that sustained systemic activation of iNKT cells had occurred, although to a weaker extent than with the tumor-targeted treatment. Serum cytokines measured $1 \mathrm{~h}$ after the third injection also reflected the prolonged reactivity of iNKT cells to tumortargeted recombinant CD1d proteins (Fig. 6c), as shown by significant serum levels of IFN $\gamma$ and IL-4 in mice treated 

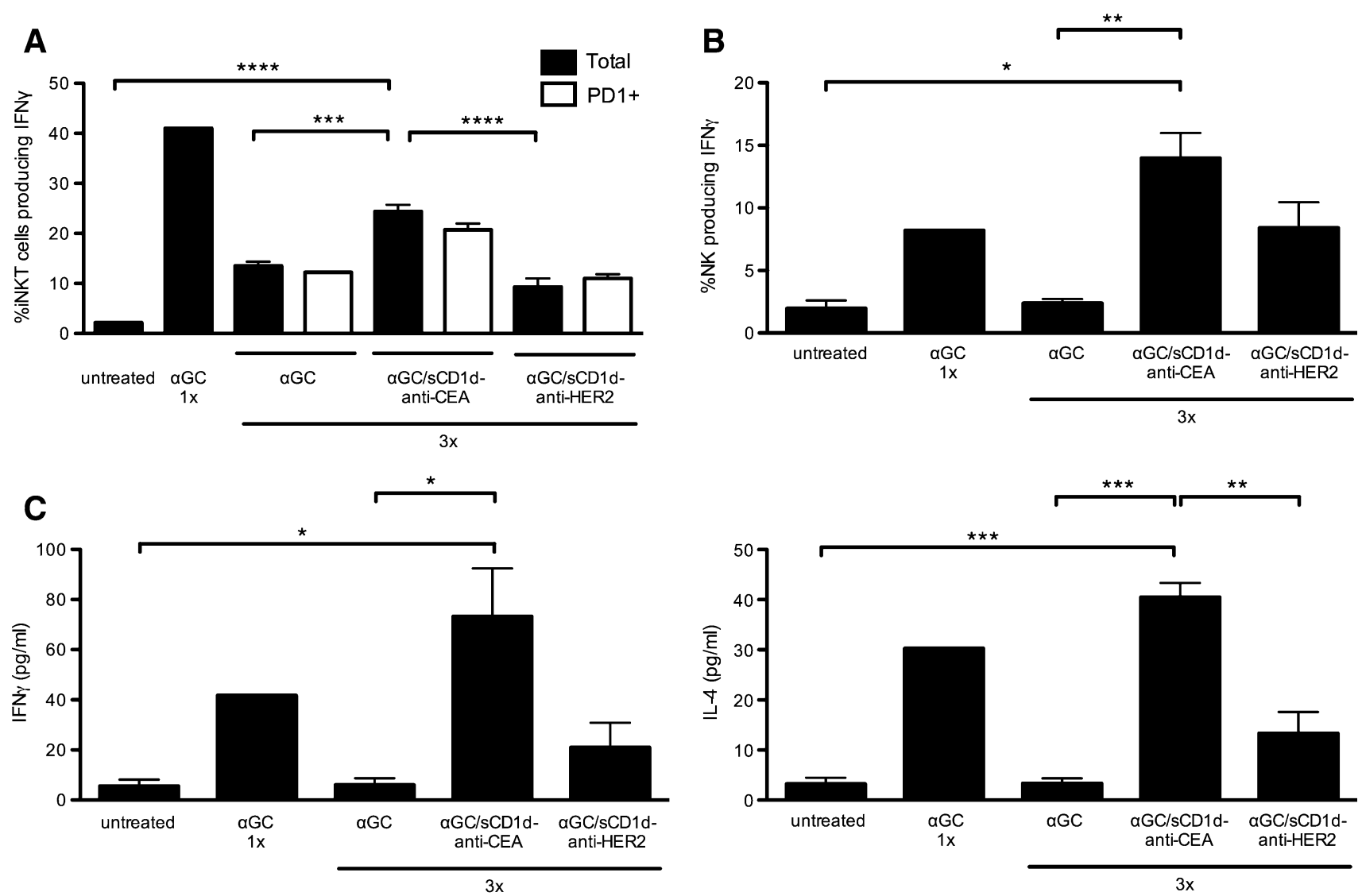

D

With tumor
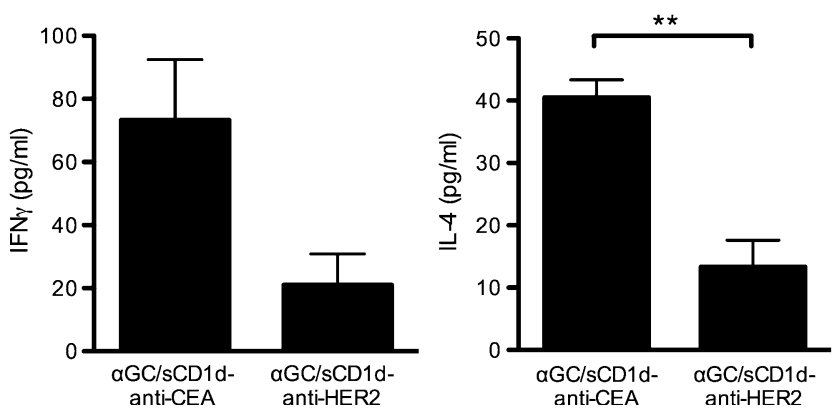

Fig. 6 Sustained activation of iNKT and NK cells upon repeated injections of tumor-targeted $\alpha \mathrm{GC} / \mathrm{sCD} 1 \mathrm{~d}-$ anti-CEA. Mice bearing MC38-CEA tumors were treated three times, following the same protocol as in the tumor therapy experiments (Fig. 5), and splenocytes were analyzed $1 \mathrm{~h}$ after the third injection. As a positive control for IFN $\gamma$ production, a naïve mouse was injected only once with $\alpha \mathrm{GC}$. a Percentage of IFN $\gamma$-producing cells gated on total (black bars) or PD- $1^{+}$(empty bars) iNKT cells. b Percentage of IFN $\gamma$-producing NK

with $\alpha \mathrm{GC} / \mathrm{sCD} 1 \mathrm{~d}-\mathrm{anti}-\mathrm{CEA}$ protein, while barely any cytokines could be measured after three injections of $\alpha \mathrm{GC}$ / sCD1d-anti-HER2 protein. Regarding $\alpha \mathrm{GC}$ as a free drug, a single injection induced a fast release of IFN $\gamma$ and IL-4, but almost no cytokine production was detected after three injections, confirming the induction of iNKT cell anergy. Most importantly, in the absence of MC38-CEA tumor
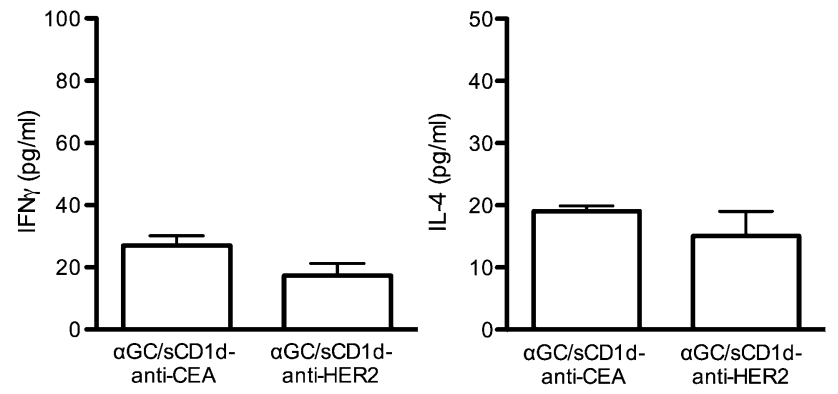

cells as gated on $\mathrm{CD}^{-} \mathrm{NK} 1.1^{+}$. $\mathbf{c}$ Cytokines were measured by CBA in the sera of mice taken $1 \mathrm{~h}$ after the third treatments, as described in a. Graphs show the concentration of IFN $\gamma$ (left panel) and IL-4 (right panel). d Serum levels of IFN $\gamma$ and IL-4 were compared between mice-bearing or not MC38-CEA tumors, and treated with targeted or non-targeted $\alpha \mathrm{GC} / \mathrm{sCD} 1 \mathrm{~d}$ fusion proteins administered as in a. All data are shown as the mean \pm SEM of 3 mice per group, ${ }^{*} P<0.01$, $* * P<0.005, * * * P<0.001, * * * * P<0.0001$

grafts, repeated treatments with $\alpha \mathrm{GC} / \mathrm{sCD} 1 \mathrm{~d}$-anti-CEA fusion protein did not lead to significant release of cytokines, which did not differ from mice treated with the irrelevant $\alpha \mathrm{GC} / \mathrm{sCD} 1 \mathrm{~d}$-anti-HER2 protein (Fig. 6d). Altogether, these results demonstrate the importance of targeting CD1d to the tumor site to favor a strong and prolonged reactivity of iNKT cells. 


\section{Discussion}

The present study demonstrates the therapeutic efficacy of recombinant $\mathrm{sCD} 1 \mathrm{~d}$-antitumor $\mathrm{scFv}$ fusion proteins via the sustained activation of murine and human cytolytic iNKT cells. The attractiveness of this strategy resides in two main beneficial characteristics. First, recombinant CD1d proteins have the capacity to keep iNKT cells reactive through multiple stimulations, in contrast to their unresponsiveness after repeated challenge by $\alpha \mathrm{GC}$-loaded APCs. Second, the targeting of CD1d molecules to cancer cells by their fusion to an antitumor scFv fragment efficiently redirects activated iNKT cells to the tumor site, promoting a local innate immune response, including direct lysis of targeted tumors by iNKT cells, release of large amounts of cytokines and transactivation of NK cells, altogether leading to prolonged antitumor effects.

So far, the therapeutic use of iNKT cells has been limited by their short-lived cytokine response to aGC stimulation, followed by a long-term anergy [4, 17, 18]. Several mechanisms have been proposed for the induction of iNKT cell unresponsiveness, and the controversial results suggest that multiple factors are likely involved. At first, the fast and long-term up-regulation of PD-1 upon activation of iNKT cells was proposed as the main mechanism since their anergic state could be prevented or reverted by PD-1/ PD-L1 blockade and did not occur in PD-1 KO mice [[28], [29]]. However, the exclusive role of PD-1 in the control of iNKT cell anergy was not confirmed in all systems [30], and the involvement of co-stimulation through CD28 or coinhibitory receptors such as BTLA was suggested [30-32]. In this respect, our present results also demonstrated the strong and long-term up-regulation of PD-1 upon activation of murine iNKT cells, which however did not correlate with the state of anergy. Indeed, iNKT cells remained reactive to multiple injections of recombinant CD1d fusion proteins despite similar up-regulation of PD-1 as was found on anergic iNKT cells after treatment with $\alpha \mathrm{GC}$ as a free drug. Clinical trials in cancer patients have preferred the autologous transfer of aGC-pulsed DC, which showed prolonged iNKT cell activation, as compared to the glycolipid alone [4, 11, 13, 14, 33]. However, a maximum of two subsequent rounds of iNKT cell stimulations were seen despite three to four autologous transfers of aGC-pulsed DC in some studies, suggesting that iNKT cells became progressively unresponsive to further challenge. Unfortunately, in vitro experiments with human iNKT cells do not allow monitoring the induction of anergy by $\alpha \mathrm{GC}$, likely due to the presence of IL-2 required for the maintenance of human and mouse iNKT cells in vitro. Indeed, IL-2 has been shown to prevent or revert the state of anergy of murine iNKT cells both in vivo and in vitro [18, 34]. However, it is interesting to note that around $70 \%$ of human iNKT cells were already expressing PD-1 when tested ex vivo on total PBMC from healthy donors, probably resulting from previous in vivo antigen stimulations. Since it is unlikely that the large majority of iNKT cells present in normal donors are anergic, the expression of PD1 on activated human and mouse iNKT cells is probably not sufficient to mediate iNKT cell unresponsiveness. So far, the exact mechanism that mediates the aGC-induced anergy of iNKT cells or, conversely, their prolonged reactivity to recombinant $\alpha \mathrm{GC} / \mathrm{CD} 1 \mathrm{~d}$ fusion proteins remains unclear.

Importantly, our data demonstrated a direct activation of human iNKT cells by recombinant soluble CD1d proteins in the absence of any APC, which excluded the possibility of loss of $\alpha \mathrm{GC}$ from the recombinant CD1d proteins and its loading onto endogenous CD1d expressed by APCs. In this regard, the capacity of a monomeric CD1d molecule to activate iNKT cells seems to be unique to this antigenpresenting molecule, as soluble MHC Class I and Class II monomers were shown to be unable to activate antigenspecific $\mathrm{T}$ cells, in contrast to dimeric and multimeric forms $[35,36]$. The question remains whether the iNKT cell activation by monomeric $\alpha \mathrm{GC} / \mathrm{sCD} 1 \mathrm{~d}$ proteins is peculiar to the strong agonist $\alpha \mathrm{GC}$ and whether it would not occur with a more physiological CD1d ligand. Nevertheless, activation of human iNKT cells by soluble $\alpha \mathrm{GC} /$ CD1d proteins remained significantly less efficient than plastic-coated or tumor bound CD1d fusion proteins and aGC-pulsed APCs, which likely resulted from the lack of molecular CD1d aggregation in the absence of plastic or cell surface, as well as from the absence of co-stimulation. In support of this, systemic treatments of mice with untargeted $\alpha \mathrm{GC} / \mathrm{sCD} 1 \mathrm{~d}$ or irrelevant $\alpha \mathrm{GC} / \mathrm{sCD} 1 \mathrm{~d}-\mathrm{scFv}$ fusion proteins led to a two to threefold weaker release of cytokines, as compared to treatment with the tumor-targeted $\alpha \mathrm{GC} / \mathrm{sCD} 1 \mathrm{~d}-\mathrm{scFv}$ protein. Rather than a drawback, the lower potency of soluble monomeric CD1d molecules will be rather favorable in limiting a potentially detrimental systemic activation of iNKT cells, while promoting their sustained activation when targeted at the tumor site.

The second attractive characteristic of our immunotherapy strategy is the targeting of recombinant CD1d fusion proteins to tumors by fusion of the extracellular part of CD1d to an antibody scFv fragment specific for a tumor antigen. Indeed, the present data show both in vitro with human iNKT cell clones and in vivo in a therapeutic mouse tumor model that the strongest tumor inhibition is obtained with tumor-targeted recombinant sCD1d-antitumor $\mathrm{scFv}$ fusion protein as compared to an irrelevant sCD1d fusion protein. This finding fits with the prerequisite of CD1d expression by tumors to promote efficient iNKT cellmediated killing, which has been previously reported in humans in the context of CD1d-expressing lymphomas 
$[26,37,38]$, and in mice with tumor models transfected with CD1d [39, 40]. In this context, our strategy using $\mathrm{CD} 1 \mathrm{~d}$-antitumor $\mathrm{scFv}$ fusion proteins opens the possibility to target CD1d-negative tumors and render them susceptible to iNKT cell attack. The effectiveness of this approach was best demonstrated by the direct cytotoxicity of human iNKT cell clones against tumor cells when coated with the $\alpha \mathrm{GC} / \mathrm{sCD} 1 \mathrm{~d}-\mathrm{scF}$ fusion protein specific for the tumor antigen expressed on their surface, while the untargeted $\alpha \mathrm{GC} / \mathrm{sCD} 1 \mathrm{~d}-\mathrm{scFv}$ was unable to induce antitumor cytotoxic activity. More importantly, although iNKT cells were strongly activated by $\alpha$ GC-pulsed APCs, such as C1R-CD1d or moDCs, as seen by CD107a expression and cytokine release, they rather killed the APCs and to a lesser extent the tumor cells, indicating that bystander killing by iNKT cells was inferior to the CD1d-mediated cytotoxicity. These observations suggest that the strategy of iNKT cell activation by autologous transfer of $\alpha \mathrm{GC}$-pulsed DCs, as tested so far in clinical trials, may direct the intrinsic cytotoxic activity of iNKT cells preferentially against the transferred DCs and not against tumors. Because of the relatively low numbers of peripheral iNKT cells in humans, this aspect was probably not a major issue, and these protocols of DC transfer have instead successfully induced the immunomodulatory functions of iNKT cells, such as the transactivation of NK and T cells. However, our results in mice demonstrated that the stronger iNKT cell activation by tumor-targeted sCD1d treatment also led to higher NK cell activation, which are known to greatly participate in tumor inhibition [19]. Therefore, the targeting of CD1d molecules to the tumor site not only triggers iNKT-mediated tumor lysis, but also favors local innate and adaptive antitumor responses, as suggested by the accumulation of iNKT, NK, and T cells at the tumor site [19]. The importance of tumor targeting and local activation of iNKT cells was underlined by recent clinical trials in which $\alpha \mathrm{GC}$ pulsed DC and/or ex vivo expanded iNKT cells were delivered in the vicinity of the tumor [15, 33]. The best clinical results were obtained in HNSCC patients in whom $\alpha$ GC-pulsed DCs were administered via the nasal submucosa and iNKT cells via the tumor-feeding arteries [15, 41]. In addition to the local delivery of iNKT cells, this encouraging clinical benefit also demonstrated the need to increase the numbers of iNKT cells by autologous transfer of in vitro expanded iNKT cell lines, since the frequency of iNKT cells is often very low or even undetectable in advanced cancer patients [8, 42]. To this aim, recombinant sCD1d-antitumor fusion proteins appear as promising tools: first, in vitro to expand large numbers of human iNKT cells for adoptive transfer, and second, in vivo to redirect these transferred iNKT cells to the tumor site.

Finally, the efficient tumor targeting of CD1d molecules requires the over-expression of a tumor antigen for which a high-affinity antibody scFv has been developed. So far, we have used two of the highest affinity existing $\mathrm{scFv}$ fragments specific for the HER2 and CEA, which are often over-expressed, respectively, in breast cancers and gastric cancers. As alternatives to tumor-associated markers, antigens over-expressed in the tumor stroma and/or neovessels would be additional good candidates for the targeting of CD1d molecules to the tumor site.

In conclusion, the present results propose and support monomeric $\mathrm{CD} 1 \mathrm{~d}-\mathrm{scFv}$ antitumor fusion proteins as a potent tool to effectively harness iNKT cells against cancer.

Acknowledgments The financial support for this study was provided by the Swiss Cancer League OCS-02248-08-2008 (S. Corgnac), Vaccinex Inc.; Rochester, NY, USA, the ISREC Cancer Foundation (L. Zhang) and the Emma Muschamp Foundation (R. Perret).

Conflict of interest All co-authors concur with the submission with no conflicting financial interest.

Open Access This article is distributed under the terms of the Creative Commons Attribution License which permits any use, distribution, and reproduction in any medium, provided the original author(s) and the source are credited.

\section{References}

1. Van Kaer L (2007) NKT cells: T lymphocytes with innate effector functions. Curr Opin Immunol 19(3):354-364. doi: 10.1016/j.coi.2007.03.001

2. Cerundolo V, Silk JD, Masri SH, Salio M (2009) Harnessing invariant NKT cells in vaccination strategies. Nat Rev Immunol 9(1):28-38. doi:10.1038/nri2451

3. Berzins SP, Smyth MJ, Baxter AG (2011) Presumed guilty: natural killer T cell defects and human disease. Nat Rev Immunol 11(2):131-142. doi:10.1038/nri2904

4. Fujii S, Shimizu K, Kronenberg M, Steinman RM (2002) Prolonged IFN-gamma-producing NKT response induced with alpha-galactosylceramide-loaded DCs. Nat Immunol 3(9): 867-874

5. Smyth MJ, Crowe NY, Pellicci DG, Kyparissoudis K, Kelly JM, Takeda K, Yagita H, Godfrey DI (2002) Sequential production of interferon-gamma by NK1.1(+) T cells and natural killer cells is essential for the antimetastatic effect of alpha-galactosylceramide. Blood 99(4):1259-1266

6. Takeda K, Hayakawa Y, Atsuta M, Hong S, Van Kaer L, Kobayashi K, Ito M, Yagita H, Okumura K (2000) Relative contribution of NK and NKT cells to the anti-metastatic activities of IL-12. Int Immunol 12(6):909-914

7. Tahir SM, Cheng O, Shaulov A, Koezuka Y, Bubley GJ, Wilson SB, Balk SP, Exley MA (2001) Loss of IFN-gamma production by invariant $\mathrm{NK} \mathrm{T}$ cells in advanced cancer. $\mathrm{J}$ Immunol 167(7):4046-4050

8. Yanagisawa K, Seino K, Ishikawa Y, Nozue M, Todoroki T, Fukao K (2002) Impaired proliferative response of V alpha 24 NKT cells from cancer patients against alpha-galactosylceramide. J Immunol 168(12):6494-6499

9. Metelitsa LS, Wu HW, Wang H, Yang Y, Warsi Z, Asgharzadeh S, Groshen S, Wilson SB, Seeger RC (2004) Natural killer T cells 
infiltrate neuroblastomas expressing the chemokine CCL2. J Exp Med 199(9):1213-1221. doi:10.1084/jem.20031462

10. Schneiders FL, de Bruin RC, van den Eertwegh AJ, Scheper RJ, Leemans CR, Brakenhoff RH, Langendijk JA, Verheul HM, de Gruijl TD, Molling JW, van der Vliet HJ (2012) Circulating invariant natural killer T-cell numbers predict outcome in head and neck squamous cell carcinoma: updated analysis with 10-year follow-up. Am J Clin Oncol 30(5):567-570. doi:10.1200/JCO. 2011.38.8819

11. Nieda M, Okai M, Tazbirkova A, Lin H, Yamaura A, Ide K, Abraham R, Juji T, Macfarlane DJ, Nicol AJ (2004) Therapeutic activation of Valpha24+ Vbeta11+ NKT cells in human subjects results in highly coordinated secondary activation of acquired and innate immunity. Blood 103(2):383-389

12. Giaccone G, Punt CJ, Ando Y, Ruijter R, Nishi N, Peters M, von Blomberg BM, Scheper RJ, van der Vliet HJ, van den Eertwegh AJ, Roelvink M, Beijnen J, Zwierzina H, Pinedo HM (2002) A phase I study of the natural killer T-cell ligand alpha-galactosylceramide (KRN7000) in patients with solid tumors. Clin Cancer Res 8(12):3702-3709

13. Ishikawa A, Motohashi S, Ishikawa E, Fuchida H, Higashino K, Otsuji M, Iizasa T, Nakayama T, Taniguchi M, Fujisawa T (2005) A phase I study of alpha-galactosylceramide (KRN7000)-pulsed dendritic cells in patients with advanced and recurrent non-small cell lung cancer. Clin Cancer Res 11(5):1910-1917

14. Chang DH, Osman K, Connolly J, Kukreja A, Krasovsky J, Pack M, Hutchinson A, Geller M, Liu N, Annable R, Shay J, Kirchhoff K, Nishi N, Ando Y, Hayashi K, Hassoun H, Steinman RM, Dhodapkar MV (2005) Sustained expansion of NKT cells and antigen-specific $\mathrm{T}$ cells after injection of alpha-galactosyl-ceramide loaded mature dendritic cells in cancer patients. J Exp Med 201(9):1503-1517

15. Kunii N, Horiguchi S, Motohashi S, Yamamoto H, Ueno N, Yamamoto S, Sakurai D, Taniguchi M, Nakayama T, Okamoto Y (2009) Combination therapy of in vitro-expanded natural killer T cells and alpha-galactosylceramide-pulsed antigen-presenting cells in patients with recurrent head and neck carcinoma. Cancer Sci 100(6):1092-1098. doi:10.1111/j.1349-7006.2009.01135.x

16. Nicol AJ, Tazbirkova A, Nieda M (2011) Comparison of clinical and immunological effects of intravenous and intradermal administration of \{alpha\}-galactosylCeramide (KRN7000)pulsed dendritic cells. Clin Cancer Res 17(15):5140-5151. doi: 10.1158/1078-0432.CCR-10-3105

17. Kawano T, Cui J, Koezuka Y, Toura I, Kaneko Y, Motoki K, Ueno H, Nakagawa R, Sato H, Kondo E, Koseki H, Taniguchi M (1997) CD1d-restricted and TCR-mediated activation of valpha14 NKT cells by glycosylceramides. Science 278(5343): 1626-1629

18. Parekh VV, Wilson MT, Olivares-Villagomez D, Singh AK, Wu L, Wang CR, Joyce S, Van Kaer L (2005) Glycolipid antigen induces long-term natural killer $\mathrm{T}$ cell anergy in mice. J Clin Invest 115(9):2572-2583

19. Stirnemann K, Romero JF, Baldi L, Robert B, Cesson V, Wurm F, Corradin G, Mach JP, Macdonald HR, Donda A (2008) Sustained activation and tumor targeting of NKT cells using a CD1danti-HER2-scFv fusion protein induce antitumor effects in mice. J Clin Invest 118(3):994-1005. doi:10.1172/JCI33249

20. Clarke P, Mann J, Simpson JF, Rickard-Dickson K, Primus FJ (1998) Mice transgenic for human carcinoembryonic antigen as a model for immunotherapy. Cancer Res 58(7):1469-1477

21. Shao Q, Ning H, Lv J, Liu Y, Zhao X, Ren G, Feng A, Xie Q, Sun J, Song B, Yang Y, Gao W, Ding K, Yang M, Hou M, Peng J, Qu $X$ (2012) Regulation of Th1/Th2 polarization by tissue inhibitor of metalloproteinase-3 via modulating dendritic cells. Blood 119(20):4636-4644. doi:10.1182/blood-2011-08-376418
22. Bricard G, Cesson V, Devevre E, Bouzourene H, Barbey C, Rufer N, Im JS, Alves PM, Martinet O, Halkic N, Cerottini JC, Romero P, Porcelli SA, Macdonald HR, Speiser DE (2009) Enrichment of human $\mathrm{CD} 4+\mathrm{V}$ (alpha)24/Vbeta11 invariant NKT cells in intrahepatic malignant tumors. J immunol 182(8):5140-5151. doi:10.4049/jimmunol.0711086

23. Hardman N, Gill LL, De Winter RF, Wagner K, Hollis M, Businger F, Ammaturo D, Buchegger F, Mach JP, Heusser C (1989) Generation of a recombinant mouse-human chimaeric monoclonal antibody directed against human carcinoembryonic antigen. Int J Cancer 44(3):424-433

24. Verhaar MJ, Chester KA, Keep PA, Robson L, Pedley RB, Boden JA, Hawkins RE, Begent RH (1995) A single chain Fv derived from a filamentous phage library has distinct tumor targeting advantages over one derived from a hybridoma. Int $\mathrm{J}$ Cancer 61(4):497-501

25. Hayakawa Y, Takeda K, Yagita H, Kakuta S, Iwakura Y, Van Kaer L, Saiki I, Okumura K (2001) Critical contribution of IFNgamma and NK cells, but not perforin-mediated cytotoxicity, to anti-metastatic effect of alpha-galactosylceramide. Eur J Immunol 31(6):1720-1727

26. Metelitsa LS (2011) Anti-tumor potential of type-I NKT cells against CD1d-positive and CD1d-negative tumors in humans. Clin immunol 140(2):119-129. doi:10.1016/j.clim.2010.10.005

27. Renukaradhya GJ, Khan MA, Vieira M, Du W, Gervay-Hague J, Brutkiewicz RR (2008) Type I NKT cells protect (and type II NKT cells suppress) the host's innate antitumor immune response to a B-cell lymphoma. Blood 111(12):5637-5645. doi: 10.1182/blood-2007-05-092866

28. Chang WS, Kim JY, Kim YJ, Kim YS, Lee JM, Azuma M, Yagita H, Kang CY (2008) Cutting edge: programmed death-1/ programmed death ligand 1 interaction regulates the induction and maintenance of invariant NKT cell anergy. J Immunol 181(10):6707-6710

29. Parekh VV, Lalani S, Kim S, Halder R, Azuma M, Yagita H, Kumar V, Wu L, Kaer LV (2009) PD-1/PD-L blockade prevents anergy induction and enhances the anti-tumor activities of glycolipid-activated invariant NKT cells. J Immunol 182(5): 2816-2826. doi:10.4049/jimmunol.0803648

30. Iyoda $\mathrm{T}$, Ushida M, Kimura $\mathrm{Y}$, Minamino K, Hayuka A, Yokohata S, Ehara H, Inaba K (2010) Invariant NKT cell anergy is induced by a strong TCR-mediated signal plus co-stimulation. Int Immunol 22(11):905-913. doi:10.1093/intimm/dxq444

31. Wang J, Cheng L, Wondimu Z, Swain M, Santamaria P, Yang Y (2009) Cutting edge: cD28 engagement releases antigen-activated invariant NKT cells from the inhibitory effects of PD-1. J immunol 182(11):6644-6647. doi:10.4049/jimmunol.0804050

32. Miller ML, Sun Y, Fu YX (2009) Cutting edge: B and T lymphocyte attenuator signaling on NKT cells inhibits cytokine release and tissue injury in early immune responses. $\mathrm{J}$ immunol 183(1):32-36. doi:10.4049/jimmunol.0900690

33. Uchida T, Horiguchi S, Tanaka Y, Yamamoto H, Kunii N, Motohashi S, Taniguchi M, Nakayama T, Okamoto Y (2008) Phase I study of alpha-galactosylceramide-pulsed antigen presenting cells administration to the nasal submucosa in unresectable or recurrent head and neck cancer. Cancer Immunol Immunother 57(3):337-345. doi:10.1007/s00262-007-0373-5

34. Schwartz RH (2003) T cell anergy. Annu Rev Immunol 21:305-334. doi:10.1146/annurev.immunol.21.120601.141110

35. Cochran JR, Cameron TO, Stern LJ (2000) The relationship of MHC-peptide binding and $\mathrm{T}$ cell activation probed using chemically defined MHC class II oligomers. Immunity 12(3):241-250

36. Stone JD, Stern LJ (2006) CD8 T cells, like CD4 T cells, are triggered by multivalent engagement of TCRs by MHC-peptide ligands but not by monovalent engagement. J immunol 176(3):1498-1505 
37. Bagnara D, Ibatici A, Corselli M, Sessarego N, Tenca C, De Santanna A, Mazzarello A, Daga A, Corvo R, De Rossi G, Frassoni F, Ciccone E, Fais F (2009) Adoptive immunotherapy mediated by ex vivo expanded natural killer $\mathrm{T}$ cells against CD1d-expressing lymphoid neoplasms. Haematologica 94(7): 967-974. doi:10.3324/haematol.2008.001339

38. Dhodapkar MV, Richter J (2011) Harnessing natural killer T (NKT) cells in human myeloma: progress and challenges. Clin Immunol 140(2):160-166. doi:10.1016/j.clim.2010.12.010

39. Shimizu K, Kurosawa Y, Taniguchi M, Steinman RM, Fujii S (2007) Cross-presentation of glycolipid from tumor cells loaded with alpha-galactosylceramide leads to potent and long-lived $\mathrm{T}$ cell mediated immunity via dendritic cells. J Exp Med 204(11):2641-2653. doi:10.1084/jem.20070458

40. Wingender G, Krebs P, Beutler B, Kronenberg M (2010) Antigen-specific cytotoxicity by invariant NKT cells in vivo is CD95/
CD178-dependent and is correlated with antigenic potency. $\mathrm{J}$ immunol 185(5):2721-2729. doi:10.4049/jimmunol.1001018

41. Yamasaki K, Horiguchi S, Kurosaki M, Kunii N, Nagato K, Hanaoka H, Shimizu N, Ueno N, Yamamoto S, Taniguchi M, Motohashi S, Nakayama T, Okamoto Y (2011) Induction of NKT cell-specific immune responses in cancer tissues after NKT celltargeted adoptive immunotherapy. Clin Immunol 138(3):255265. doi:10.1016/j.clim.2010.11.014

42. Molling JW, Langius JA, Langendijk JA, Leemans CR, Bontkes HJ, van der Vliet HJ, von Blomberg BM, Scheper RJ, van den Eertwegh AJ (2007) Low levels of circulating invariant natural killer $\mathrm{T}$ cells predict poor clinical outcome in patients with head and neck squamous cell carcinoma. J Clin Oncol 25(7):862-868. doi:10.1200/JCO.2006.08.5787 